Article

\title{
Aminodi(hetero)arylamines in the Thieno[3,2-b]pyridine Series: Synthesis, Effects in Human Tumor Cells Growth, Cell Cycle Analysis, Apoptosis and Evaluation of Toxicity Using Non-Tumor Cells
}

Ricardo C. Calhelha ${ }^{1,2}$, Isabel C. F. R. Ferreira ${ }^{2, *}$, Daniela Peixoto ${ }^{1}$, Rui M. V. Abreu ${ }^{2}$, Luís A. Vale-Silva ${ }^{3,4}$, Eugénia Pinto ${ }^{3,4}$, Raquel T. Lima ${ }^{4,5}$, M. Inês Alvelos ${ }^{5}$,

M. Helena Vasconcelos ${ }^{3,5}$ and Maria-João R. P. Queiroz ${ }^{1, *}$

1 Center of Chemistry, University of Minho, Campus de Gualtar 4710-057 Braga, Portugal

2 CIMO-ESA, Instituto Politécnico de Bragança, Campus de Sta Apolónia, Apartado 1172, 5301-855 Bragança, Portugal

3 Department of Biological Sciences, Faculty of Pharmacy of the University of Porto, Rua de Jorge Viterbo Ferreira n. ${ }^{\circ} 228$, 4050-313 Porto, Portugal

4 CEQUIMED-UP, Research Center of Medicinal Chemistry, University of Porto, Rua de Jorge Viterbo Ferreira n. ${ }^{\circ} 228,4050-313$ Porto, Portugal

5 Cancer Drug Resistance Group, IPATIMUP-Institute of Molecular Pathology and Immunology of the University of Porto, Rua Dr. Roberto Frias s/n, 4200-465 Porto, Portugal

* Authors to whom correspondence should be addressed; E-Mails: iferreira@ipb.pt (I.C.F.R.F.); mjrpq@quimica.uminho.pt (M.-J.R.P.Q.); Tel.: +351-273303219 (I.C.F.R.F.);

Fax: +351-273325405 (I.C.F.R.F.); Tel.: +351-253604378 (M.-J.R.P.Q.);

Fax: +351-253604382 (M.-J.R.P.Q.).

Received: 12 March 2012; in revised form: 24 March 2012 / Accepted: 26 March 2012 /

Published: 28 March 2012

Abstract: Three aminodi(hetero)arylamines were prepared via a palladium-catalyzed C-N Buchwald-Hartwig coupling of methyl 3-aminothieno[3,2-b]pyridine-2-carboxylate with different bromonitrobenzenes, followed by reduction of the nitro groups of the coupling products to the corresponding amino compounds. The aminodi(hetero)arylamines thus obtained were evaluated for their growth inhibitory effect on four human tumor cell lines MCF-7 (breast adenocarcinoma), A375-C5 (melanoma), NCI-H460 (non-small cell lung cancer) and $\mathrm{HepG}_{2}$ (hepatocellular carcinoma). The toxicity to non-tumor cells was also evaluated using a porcine liver primary cell culture (PLP1), established by us. The aminodi(hetero)arylamine with the $\mathrm{NH}_{2}$ group in the ortho position and an OMe group in 
the para position to the $\mathrm{NH}$ of the di(hetero)arylamine, is the most promising compound giving the lowest $\mathrm{GI}_{50}$ values $(1.30-1.63 \mu \mathrm{M})$ in all the tested human tumor cell lines, presenting no toxicity to PLP1 at those concentrations. The effect of this compound on the cell cycle and induction of apoptosis was analyzed in the NCI-H460 cell line. It was observed that it altered the cell cycle profile causing a decrease in the percentage of cells in the $\mathrm{G} 0 / \mathrm{G} 1$ phase and an increase of the apoptosis levels.

Keywords: thieno[3,2-b]pyridines; aminodi(hetero)arylamines; Buchwald-Hartwig C-N coupling; antitumoral activity; toxicity; cell cycle; apoptosis

\section{Introduction}

Despite the great amount of research and rapid development of new therapies seen during the past decade, cancer continues to be a leading cause of death worldwide. It is estimated that by 2020 approximately 15 million new cancer cases will be diagnosed and 12 million patients will die every year [1]. Although conventional anti-cancer therapies in current clinical use (such as anti-hormonal therapy, radiotherapy and chemotherapy) improve patient survival, the resulting drug toxicity and severe side effects are still causing high failure rates of cure. In addition, when organ-confined tumors advance to locally invasive or metastatic stages, this usually associates to resistance to conventional therapies, disease relapse, and to patient death within a short period of time [2].

Several thienopyridines have already been described as inhibitors of cell proliferation in in vitro tumoral cell line assays $[3,4]$, highlighting the interest of studying their anti-tumoral activity. Our research group has also synthesized various methyl 3-aminothieno[3,2-b]pyridine-2-carboxylate derivatives functionalized at the pyridine ring by Pd-catalyzed C-N (Buchwald-Hartwig) and C-C (Suzuki and Sonogashira) couplings and some of them presented cell growth inhibitory activity in tumor cell lines [5-7]. Among the 6-(hetero)arylaminothieno[3,2-b]pyridine derivatives obtained by C-N coupling the most promising compounds bear a benzothiazole $\left(\mathrm{GI}_{50} 3.5-6.4 \mu \mathrm{M}\right)$ or an indole $\left(\mathrm{GI}_{50} 15.8-18.1 \mu \mathrm{M}\right)$ moiety [5].

In the present work, three aminodi(hetero)arylamines in the thieno[3,2-b]pyridine series functionalized at the thiophene ring were synthesized from the corresponding nitro compounds. The aminodi(hetero)arylamines were evaluated for their in vitro growth inhibitory effect on four human tumor cell lines [MCF-7 (breast adenocarcinoma), NCI-H460 (non-small cell lung cancer), A375-C5 (melanoma) and $\mathrm{HepG}_{2}$ (hepatocellular carcinoma)] and also on the non-tumor primary cells PLP1 (porcine liver primary cell culture) established by us. For the most active and less toxic compound, its effects on cell cycle and induction of apoptosis were evaluated using the NCI-H460 cell line.

\section{Results and Discussion}

\subsection{Synthesis}

Reacting methyl 3-aminothieno[3,2-b]pyridine-2-carboxylate (1) [8] with different bromo-nitrobenzenes under Pd-catalyzed Buchwald-Hartwig C-N coupling conditions (i) using xantphos as the ligand and $\mathrm{Cs}_{2} \mathrm{CO}_{3}$ as the base, the di(hetero)arylnitro compounds $\mathbf{2 a}-\mathbf{c}$ were obtained 
in high yields. These conditions were already used by others [9] and by some of us [10] for the C-N coupling of deactivated amines, with good results. The nitro compounds $\mathbf{2 a}-\mathbf{c}$ were reduced in almost quantitative yield to the corresponding aminodi(hetero)arylamines $\mathbf{3 a}-\mathbf{c}$ using conditions; (ii) [11] depicted in Scheme 1. The synthesis of compounds $\mathbf{2 a}, \mathbf{2 b}$ and $\mathbf{3 a}, \mathbf{3 b}$ was already schematically presented by us in an earlier short communication [12], but the experimental procedure of their synthesis and their complete characterization are described here for the first time, together with compounds $\mathbf{2 c}$ and $\mathbf{3 c}$.

Scheme 1. Synthesis of di(hetero)arylnitro compounds 2a-c by Buchwald-Hartwig C-N coupling and their reduction to the aminodi(hetero)arylamines $\mathbf{3 a}-\mathbf{c}$.

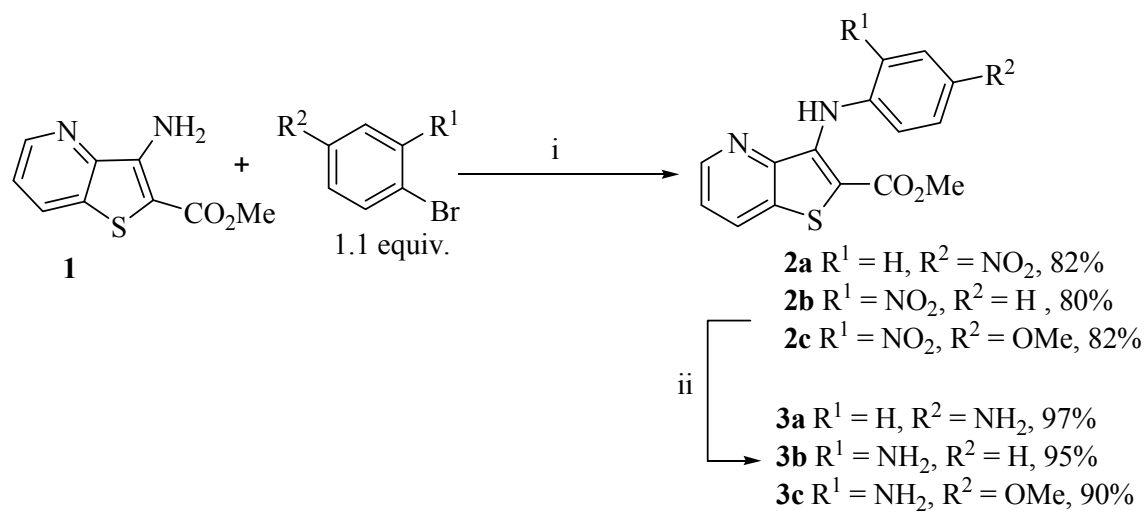

i) $\mathrm{Pd}(\mathrm{OAc})_{2}\left(15 \mathrm{~mol} \%\right.$ ), xantphos (18 mol\%), $\mathrm{Cs}_{2} \mathrm{CO}_{3}$ ( 2 equiv.), dry dioxane, $2 \mathrm{~h}, 120^{\circ} \mathrm{C}$.

ii) $\mathrm{NH}_{4} \mathrm{Cl}$ (1 equiv.), $\mathrm{Fe}\left(8\right.$ equiv.), EtOH/THF/ $\mathrm{H}_{2} \mathrm{O}(3: 1: 0.5), 100{ }^{\circ} \mathrm{C}, 2 \mathrm{~h}$.

\subsection{Cell Growth Inhibitory Activity and Toxicity to Non-Tumor Cells}

The effects of the aminodi(hetero)arylamines in the growth of four human tumour cell lines (MCF-7, A375-C5, NCI-H460 and $\mathrm{HepG}_{2}$ ) were evaluated using the SRB assay. The results, represented as the concentrations that caused $50 \%$ of cell growth inhibition $\left(\mathrm{GI}_{50}\right)$, are summarized in Table 1. Doxorubicin and ellipticine were used as positive controls. Furthermore, to investigate the possible toxicity of the compounds, the in vitro cell growth inhibition assay (SRB) was also performed using porcine liver non-tumor cells (PLP1) established by us.

From the analysis of Table 1 it is possible to conclude that the compound $\mathbf{3 c}$ with the amino group in the ortho position and a methoxy group in the para position presented the lowest $\mathrm{GI}_{50}$ values $(<2 \mu \mathrm{M})$ in all the tested human tumour cell lines. Moreover, those values were always lower than the $\mathrm{GI}_{50}$ value found in the toxicity assay, when using the porcine liver non-tumor cells (PLP1). It is also observed that the presence of the amino group in the ortho position to the $\mathrm{NH}$ in compound $\mathbf{3 b}$ significantly decreased the $\mathrm{GI}_{50}$ values when compared to the presence of the amino group in the para position in compound 3a. 
Table 1. $\mathrm{GI}_{50}$ values $^{\mathrm{a}}(\mu \mathrm{M})$ for the aminodi(hetero)arylamines $\mathbf{3 a}-\mathbf{c}$ and for the controls doxorubicin and ellipticine (mean $\pm \mathrm{SD} ; \mathrm{n}=3$ ).

\begin{tabular}{lccccc}
\hline & MCF-7 & A375-C5 & NCI-H460 & HepG2 & PLP1 \\
\hline Ellipticine & & & & & \\
\hline
\end{tabular}

${ }^{\mathrm{a}}$ Results represent the $\mathrm{GI}_{50}$ concentrations (concentrations that were able to cause $50 \%$ of cell growth inhibition) determined following a $48 \mathrm{~h}$ continuous treatment.

The effect of the most promising compound $\mathbf{3 c}$ in the cell cycle profile was then analyzed in the NCI-H460 cells. The results, presented in Figure 1, show that this compound caused a significant decrease in the percentage of cells in the G0/G1 phase of the cell cycle.

Figure 1. Cell cycle analysis of NCI-H460 cells treated with compound $\mathbf{3 c}$ at its $\mathrm{GI}_{50}$ concentration $(1.4 \mu \mathrm{M})$. Untreated cells (blank) and compound vehicle (DMSO) were used as controls. Results are the mean \pm SEM of three independent experiments.

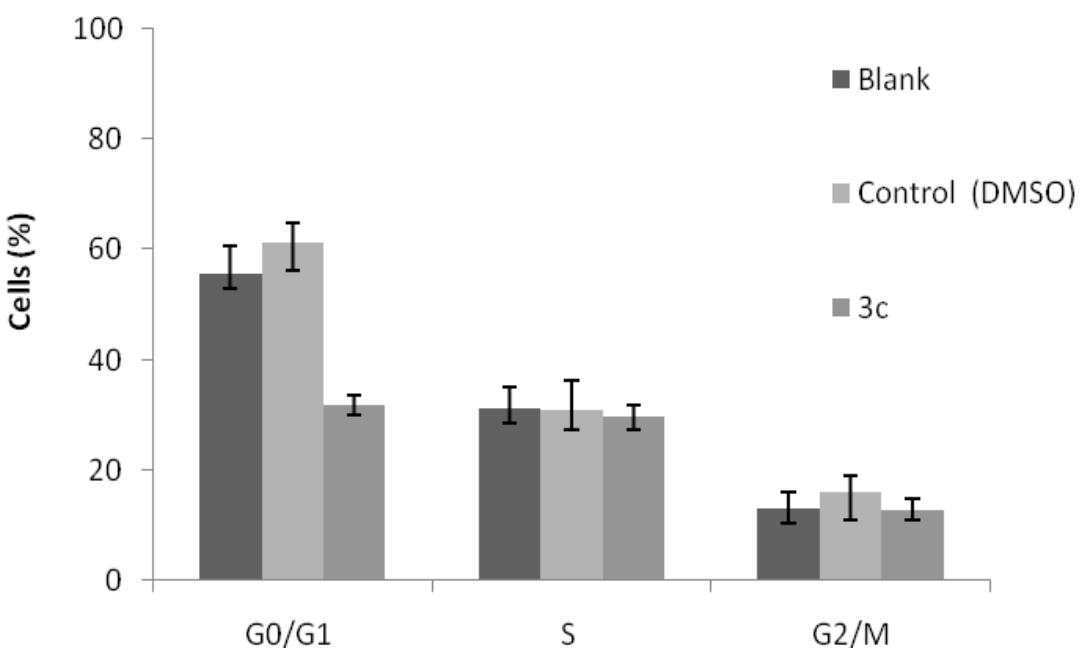

In addition the compound 3c significantly increased the \% of cells in the sub-G1 peak (data not shown), which is indicative of apoptosis. In order to confirm this, flow cytometry analysis was carried out following Annexin V/Propidium iodide staining. Results clearly showed that compound 3c statistically increased the percentage of apoptotic cells, from $6.5 \pm 1.1 \%$ in blank cells (or $4.2 \pm 0.4 \%$ in treated cells with DMSO) to $36.6 \pm 4.8 \%$ in treated cells with compound $3 \mathbf{c}$. 


\section{Experimental}

\subsection{Synthesis}

Melting points $\left({ }^{\circ} \mathrm{C}\right)$ were determined in a Stuart SMP3 and are uncorrected. ${ }^{1} \mathrm{H}$ - and ${ }^{13} \mathrm{C}-\mathrm{NMR}$ spectra were recorded on a Varian Unity Plus at 300 and $75.4 \mathrm{MHz}$, respectively or on a Bruker Avance III at 400 and $100.6 \mathrm{MHz}$, respectively. Two dimensional ${ }^{1} \mathrm{H}-{ }^{13} \mathrm{C}$ correlations were performed to attribute some signals. HRMS using EI was performed by the mass spectrometry service of the University of Vigo, C.A.C.T.I., Spain. The reactions were monitored by thin layer chromatography (TLC) using Macherey-Nagel pre-coated aluminium silica gel 60 sheets $(0.20 \mathrm{~mm})$ with UV254 indicator. Dry-flash cromatography was performed on Panreac, Silica Gel 60, 40-63 microns. Ether refers to diethylether. Xantphos refers to 8,9-dimethyl-4,5-bis(diphenylphosphane)xanthene.

\subsubsection{General Procedure for the Synthesis of Nitrodiarylamines $\mathbf{2 a}-\mathbf{c}$}

A dry Schlenk tube was charged under Ar with dry dioxane $(3 \mathrm{~mL})$, the bromonitrobenzene (1.1 equiv.), $\mathrm{Pd}(\mathrm{OAc})_{2}$ (15 mol\%), Xantphos (18 mol\%), $\mathrm{Cs}_{2} \mathrm{CO}_{3}$ (2 equiv.) and the methyl 3-aminothieno[3,2-b]pyridine-2-carboxylate (1), and the mixture was heated under $\mathrm{Ar}$ at $120{ }^{\circ} \mathrm{C}$ for $2 \mathrm{~h}$. After cooling water $(5 \mathrm{~mL})$ and ethyl acetate $(5 \mathrm{~mL})$ were added. The phases were separated and the aqueous phase was extracted with more ethyl acetate $(2 \times 5 \mathrm{~mL})$. The organic phase was dried $\left(\mathrm{MgSO}_{4}\right)$ and filtered. Removal of the solvent gave a brown solid which was submitted to dry flash using ether and a solid was obtained.

Methyl 3-(4-nitrophenylamino)thieno[3,2-b]pyridine-2-carboxylate (2a): From thienopyridine 1 (150 mg, $0.724 \mathrm{mmol}$ ) and 1-bromo-4-nitrobenzene (161 mg, $0.796 \mathrm{mmol})$, compound 2a was isolated as a brownish solid (195 mg, 82\%), m.p. 203-205 ${ }^{\circ} \mathrm{C} .{ }^{1} \mathrm{H}-\mathrm{NMR}\left(400 \mathrm{MHz}, \mathrm{DMSO}-d_{6}\right): \delta=3.96$ (s, $3 \mathrm{H}, \mathrm{OMe}), 7.08$ (d, $J=9.2 \mathrm{~Hz}, 2 \mathrm{H}, 2^{\prime}$ and $\left.6^{\prime}-\mathrm{H}\right), 7.43(\mathrm{dd}, J=8.2$ and $4.2 \mathrm{~Hz} 1 \mathrm{H}, 6-\mathrm{H}), 8.13(\mathrm{~d}$, $J=9.2 \mathrm{~Hz}, 2 \mathrm{H}, 3^{\prime}$ and $\left.5^{\prime}-\mathrm{H}\right), 8.19(\mathrm{dd}, J=8.2$ and $1.6 \mathrm{~Hz}, 1 \mathrm{H}, 7-\mathrm{H}), 8.67(\mathrm{dd}, J=4.2$ and $1.6 \mathrm{~Hz}, 1 \mathrm{H}$, 5-H), 8.76 (br s, $1 \mathrm{H}, \mathrm{NH}) \mathrm{ppm} .{ }^{13} \mathrm{C}-\mathrm{NMR}\left(100.6 \mathrm{MHz}, \mathrm{DMSO}-d_{6}\right): \delta=52.5(\mathrm{OMe}), 113.8(\mathrm{C}-2)$, $118.2\left(2^{\prime}\right.$ and $\left.6^{\prime}-\mathrm{CH}\right), 122.1(6-\mathrm{CH}), 124.9\left(3^{\prime}\right.$ and 5'-CH), $131.5(7-\mathrm{CH}), 134.2(\mathrm{C}), 141.7(\mathrm{C}), 141.8$ (C), 147.2 (5-CH), 147.6 (C-3), 148.0 (C-1'), $164.5(\mathrm{C}=\mathrm{O})$ ppm. HRMS (EI) Calcd. for $\mathrm{C}_{15} \mathrm{H}_{11} \mathrm{~N}_{3} \mathrm{O}_{4} \mathrm{~S}$ $\left[\mathrm{M}^{+}\right]$329.0470; found 329.0479.

Methyl 3-(2-nitrophenylamino)thieno[3,2-b]pyridine-2-carboxylate (2b): From thienopyridine 1 (150 mg, $0.724 \mathrm{mmol}$ ) and 1-bromo-2-nitrobenzene (161 mg, $0.796 \mathrm{mmol})$, compound $\mathbf{2 b}$ was isolated as a reddish solid (190 mg, 80\%), m.p. $202-204{ }^{\circ} \mathrm{C} .{ }^{1} \mathrm{H}-\mathrm{NMR}\left(400 \mathrm{MHz}, \mathrm{DMSO}-d_{6}\right): \delta=3.97$ (s, 3H, OMe), 6.93-7.00 (m, 2H, 6' and $\left.5^{\prime}-\mathrm{H}\right), 7.32-7.37\left(\mathrm{~m}, 1 \mathrm{H}, 4^{\prime}-\mathrm{H}\right), 7.42(\mathrm{dd}, J=8.2$ and $4.4 \mathrm{~Hz}, 1 \mathrm{H}$, 6-H), 8.19-8.22 (m, 2H, $3^{\prime}$ and 7-H), 8.67 (dd, $1 \mathrm{H}, J=4.4$ and $\left.1.6 \mathrm{~Hz}, 5-\mathrm{H}\right), 10.59$ (br s, 1H, NH) ppm. ${ }^{13} \mathrm{C}-\mathrm{NMR}\left(100.6 \mathrm{MHz}, \mathrm{DMSO}-d_{6}\right): \delta=52.7$ (OMe), $118.6(\mathrm{C}-2), 119.9\left(5^{\prime}-\mathrm{CH}\right), 120.1\left(6^{\prime}-\mathrm{CH}\right), 121.8$ (6-CH), 125.9 (3'-CH), 131.4 (7-CH), 133.9 (4'-CH), $134.00\left(\mathrm{C}-1^{\prime}\right), 135.9$ (C), 139.2 (C), 139.3 (C), $147.4(5-\mathrm{CH}), 148.3(\mathrm{C}), 163.3(\mathrm{C}=\mathrm{O})$ ppm. HRMS (EI) Calcd. for $\mathrm{C}_{15} \mathrm{H}_{11} \mathrm{~N}_{3} \mathrm{O}_{4} \mathrm{~S}\left[\mathrm{M}^{+}\right]$329.0470; found 329.0478 . 
Methyl 3-(4-methoxy-2-nitrophenylamino)thieno[3,2-b]pyridine-2-carboxylate (2c): From thieno-pyridine 1 (150 mg, $0.724 \mathrm{mmol}$ ) and 4-bromo-3-nitroanisole (185 mg, $0.796 \mathrm{mmol})$, compound $2 \mathrm{c}$ was isolated as a reddish solid (220 mg, 82\%), m.p. $213-214{ }^{\circ} \mathrm{C} .{ }^{1} \mathrm{H}-\mathrm{NMR}\left(400 \mathrm{MHz}, \mathrm{DMSO}-d_{6}\right): \delta=3.82$ (s, 3H, OMe), 3.87 (s, 3H, OMe), 7.02 (d, $\left.J=9.2 \mathrm{~Hz}, 1 \mathrm{H}, 6^{\prime}-\mathrm{H}\right), 7.14(\mathrm{dd}, J=9.2$ and $2.8 \mathrm{~Hz}, 1 \mathrm{H}$, $\left.5^{\prime}-\mathrm{H}\right), 7.53-7.58\left(\mathrm{~m}, 2 \mathrm{H}, 3^{\prime}\right.$ and 6-H), $8.55(\mathrm{dd}, J=8.4$ and $1.6 \mathrm{~Hz}, 1 \mathrm{H}, 7-\mathrm{H}), 8.60$ (dd, $J=4.4$ and $1.6 \mathrm{~Hz}, 1 \mathrm{H}, 5-\mathrm{H}), 9.72$ (br s, $1 \mathrm{H}, \mathrm{NH}) \mathrm{ppm} .{ }^{13} \mathrm{C}-\mathrm{NMR}\left(100.6 \mathrm{MHz}, \mathrm{DMSO}-d_{6}\right): \delta=52.5(\mathrm{OMe}), 55.8$ (OMe), 107.2 (3'-CH), 114.3 (C-2'), 122.5 (6-CH), 122.9 (5'-CH), 123.5 (6'-CH), $132.1(\mathrm{C}), 132.4$ (7-CH), 133.5 (C), 136.8 (C-1'), 139.9 (C), $147.1(\mathrm{C}), 147.4(5-\mathrm{CH}), 153.2(\mathrm{C}-2), 163.3(\mathrm{C}=\mathrm{O}) \mathrm{ppm}$. HRMS (EI) Calcd. for $\mathrm{C}_{16} \mathrm{H}_{13} \mathrm{~N}_{3} \mathrm{O}_{5} \mathrm{~S}\left[\mathrm{M}^{+}\right]$359.0576; found 359.0559.

\subsubsection{General Procedure for the Synthesis of Aminodiarylamines 3a-c}

In a round bottom flask with $4.5 \mathrm{~mL}$ EtOH/THF/ $\mathrm{H}_{2} \mathrm{O}$ (3:1:0.5), compounds $\mathbf{2 a}-\mathbf{c}, \mathrm{NH}_{4} \mathrm{Cl}$ (1 equiv.), Fe ( 8 equiv.) were heated at $100{ }^{\circ} \mathrm{C}$ for $2 \mathrm{~h}$. After cooling the mixture was evaporated to give a dark solid. This was submitted to dry-flash using ether and the product was obtained as a yellow or greenish solid.

Methyl 3-(4-aminophenylamino)thieno[3,2-b]pyridine-2-carboxylate (3a): From nitrodiarylamine 2a (100 mg, $0.304 \mathrm{mmol}$ ) compound 3a was isolated as a greenish solid (88.0 mg, 97\%), m.p. 200-202 ${ }^{\circ} \mathrm{C}$. ${ }^{1} \mathrm{H}-\mathrm{NMR}\left(300 \mathrm{MHz}, \mathrm{DMSO}-d_{6}\right): \delta=3.77$ (s, 3H, OMe), 4.84 (br s, $2 \mathrm{H}, \mathrm{NH}_{2}$ ), 6.45 (d, $J=8.4 \mathrm{~Hz}, 2 \mathrm{H}$, $3^{\prime}$ and $\left.5^{\prime}-\mathrm{H}\right), 6.77\left(\mathrm{~d}, J=8.4 \mathrm{~Hz}, 2 \mathrm{H}, 2^{\prime}\right.$ and $\left.6^{\prime}-\mathrm{H}\right), 7.46(\mathrm{dd} J=8.2$ and $4.2 \mathrm{~Hz}, 1 \mathrm{H}, 6-\mathrm{H}), 8.39$ (dd, $J=8.2$ and $1.6 \mathrm{~Hz}, 1 \mathrm{H}, 7-\mathrm{H}), 8.51$ (dd, $J=4.2$ and $1.6 \mathrm{~Hz}, 1 \mathrm{H}, 5-\mathrm{H}), 8.60$ (br s, 1H, NH) ppm. ${ }^{13} \mathrm{C}-\mathrm{NMR}\left(75.4 \mathrm{MHz}, \mathrm{DMSO}-d_{6},\right): \delta=51.9(\mathrm{OMe}), 103.6(\mathrm{C}), 113.7\left(3^{\prime}\right.$ and $\left.5^{\prime}-\mathrm{CH}\right), 122.3(6-\mathrm{CH})$, $123.0\left(2^{\prime}\right.$ and 6'-CH), $130.9(\mathrm{C}), 131.8$ (7-CH), $133.7(\mathrm{C}), 144.9\left(\mathrm{C}-4^{\prime}\right), 145.3(\mathrm{C}), 146.4(5-\mathrm{CH}), 147.2$ (C), $164.4(\mathrm{C}=\mathrm{O})$ ppm. HRMS (EI) Calcd. for $\mathrm{C}_{15} \mathrm{H}_{13} \mathrm{~N}_{3} \mathrm{O}_{2} \mathrm{~S}\left[\mathrm{M}^{+}\right]$299.0728; found 299.0732.

Methyl 3-(2-aminophenylamino)thieno[3,2-b]pyridine-2-carboxylate (3b): From nitrodiarylamine $\mathbf{2 b}$ (100 mg, $0.304 \mathrm{mmol})$ compound $\mathbf{3 b}$ was isolated as a greenish solid $(86.0 \mathrm{mg}, 95 \%)$, m.p. $204-206{ }^{\circ} \mathrm{C}$. ${ }^{1} \mathrm{H}-\mathrm{NMR}$ (400 MHz, DMSO-d $\left.d_{6}\right): \delta=3.79$ (s, 3H, OMe), 4.97 (br s, 2H, NH 2$), 6.39$ (m, 1H, ArH), 6.63-6.83 (m, 3H, ArH), 7.48 (m, 1H, 6-H), 8.12 (br s, 1H, NH), 8.42-8.52 (m, 2H, 7 and 5-H) ppm. ${ }^{13} \mathrm{C}-\mathrm{NMR}\left(100.6 \mathrm{MHz}, \mathrm{DMSO}-d_{6}\right): \delta=52.0(\mathrm{OMe}), 105.9(\mathrm{C}-2), 114.9(\mathrm{CH}), 115.9(\mathrm{CH}), 122.2(\mathrm{CH})$, $122.3(6-\mathrm{CH}), 124.1(\mathrm{CH}), 127.9(\mathrm{C}), 131.8(7-\mathrm{CH}), 133.6(\mathrm{C}), 141.2(\mathrm{C}), 145.2(\mathrm{C}), 146.7(5-\mathrm{CH})$, 147.2 (C), $164.2(\mathrm{C}=\mathrm{O})$ ppm. HRMS (EI) Calcd. for $\mathrm{C}_{15} \mathrm{H}_{13} \mathrm{~N}_{3} \mathrm{O}_{2} \mathrm{~S}\left[\mathrm{M}^{+}\right]$299.0728; found 299.0726.

Methyl 3-(2-amino-4-methoxhyphenylamino)thieno[3,2-b]pyridine-2-carboxylate (3c): From nitro-diarylamine $2 \mathbf{c}(100 \mathrm{mg}, 0.278 \mathrm{mmol})$ compound $\mathbf{3 c}$ was isolated as a greenish solid $(83.0 \mathrm{mg}$, 90\%), m.p. $172-174{ }^{\circ} \mathrm{C} .{ }^{1} \mathrm{H}-\mathrm{NMR}\left(400 \mathrm{MHz}, \mathrm{DMSO}-d_{6}\right): \delta=3.65$ (s, 3H, OMe), 3.79 (s, 3H, OMe), 5.00 (br s, 2H, $\mathrm{NH}_{2}$ ), 5.99 (dd, $J=8.8$ and $\left.2.4 \mathrm{~Hz}, 1 \mathrm{H}, 5^{\prime}-\mathrm{H}\right), 6.31$ (d, $\left.J=2.4 \mathrm{~Hz}, 1 \mathrm{H}, 3^{\prime}-\mathrm{H}\right), 6.61$ (d, $\left.J=8.8 \mathrm{~Hz}, 1 \mathrm{H}, 6^{\prime}-\mathrm{H}\right), 7.43$ (dd, $J=8.2$ and $\left.4.4 \mathrm{~Hz}, 1 \mathrm{H}, 6-\mathrm{H}\right), 8.09$ (br s, $\left.1 \mathrm{H}, \mathrm{NH}\right), 8.38$ (dd, $J=8.2$ and $1.6 \mathrm{~Hz}, 1 \mathrm{H}, 7-\mathrm{H}), 8.47$ (dd, $J=4.4$ and $1.6 \mathrm{~Hz}, 1 \mathrm{H}, 5-\mathrm{H}) \mathrm{ppm} .{ }^{13} \mathrm{C}-\mathrm{NMR}\left(100.6 \mathrm{MHz}, \mathrm{DMSO}-d_{6}\right)$ : $\delta=51.9(\mathrm{OMe}), 54.8(\mathrm{OMe}), 100.0\left(3^{\prime}-\mathrm{CH}\right), 101.2\left(5^{\prime}-\mathrm{CH}\right), 103.4(\mathrm{C}), 120.9(\mathrm{C}), 122.2(6-\mathrm{CH}), 124.9$ (6'-CH), 131.7 (7-CH), 133.68 (C), 143.7 (C), 146.5 (C), 146.5 (5-CH), 147.0 (C), 157.2 (C-4'), 164.6 $(\mathrm{C}=\mathrm{O})$ ppm. HRMS (EI) Calcd. for $\mathrm{C}_{16} \mathrm{H}_{15} \mathrm{~N}_{3} \mathrm{O}_{3} \mathrm{~S}\left[\mathrm{M}^{+}\right]$329.0834; found 329.0827. 


\subsection{Cell Growth Inhibitory Activity and Toxicity to Non-Tumor Cells}

\subsubsection{Standards and Reagents}

DMSO (dimethyl sulfoxide) was analytical grade from Fisher Scientific (Paris, France). Fetal bovine serum (FBS), L-glutamine, hank's balanced salt solution (HBSS), trypsin-EDTA (ethylenediaminetetraacetic acid), penincillin/streptomycin solution $(100 \mathrm{U} / \mathrm{mL}$ and $100 \mathrm{mg} / \mathrm{mL}$, respectively) and RNAse A were from Gibco Invitrogen Co. (Paisley, UK). RPMI-1640 medium was from Cambrex (East Rutherford, NJ, USA) and DMEM medium was from Hyclone (Logan, UT, USA). Acetic acid, ellipticine, doxorubicin, sulforhodamine B (SRB), trypan blue, trichloroacetic acid (TCA), Tris and propidium iodide were from Sigma Chemical Co. (St. Louis, MO, USA). Water was treated in a Mili-Q water purification system (TGI Pure Water Systems, Greenville, SC, USA).

\subsubsection{Solutions of the Compounds}

Stock solutions of the tested aminodiarylamines were prepared in DMSO and kept at $-20{ }^{\circ} \mathrm{C}$. Appropriate dilutions were prepared in the corresponding solvent prior to the assays. The effect of DMSO on the growth of the cell lines was evaluated by treating cells with the maximum concentration of DMSO used in the assays $(0.25 \%)$. No influence was found (data not shown).

\subsubsection{Cell Culture of Cell Lines and of Porcine liver Primary Cells}

Four human tumor cell lines, MCF-7 (breast adenocarcinoma), A375-C5 (melanoma), NCI-H460 (non-small cell lung cancer) and HepG2 (hepatocellular carcinoma) were used. MCF-7, A375-C5 and HepG2 were obtained from the European Collection of Cell Cultures (ECACC, Salisbury, UK) and NCI-H460 was kindly provided by the National Cancer Institute (NCI, Bethesda, MD, USA). Cells were routinely maintained as adherent cell cultures in RPMI-1640 medium supplemented with 5\% FBS (MCF-7, NCI-H460 and A375-C5 cells) or in DMEM supplemented with 10\% FBS, 2 mM glutamine, $100 \mathrm{U} / \mathrm{mL}$ penicillin and $100 \mathrm{mg} / \mathrm{mL}$ streptomycin $\left(\mathrm{HepG}_{2}\right.$ cells), at $37{ }^{\circ} \mathrm{C}$ in a humidified atmosphere containing $5 \% \mathrm{CO}_{2}$.

Porcine liver primary cell culture (PLP1) was prepared from freshly harvested porcine liver, obtained from a local slaughter house. Briefly, the liver tissue was rinsed in HBSS solution containing $100 \mathrm{U} / \mathrm{mL}$ penicillin, $100 \mu \mathrm{g} / \mathrm{mL}$ streptomycin and divided into $1 \times 1 \mathrm{~mm}^{3}$ explants. Some of these explants were placed in $25 \mathrm{~cm}^{2}$ tissue flasks in DMEM medium supplemented with $10 \% \mathrm{FBS}, 2 \mathrm{mM}$ nonessential amino acids, $100 \mathrm{U} / \mathrm{mL}$ penicillin and $100 \mathrm{mg} / \mathrm{mL}$ streptomycin. This cell culture was maintained according to the procedure described previously by us [13].

\subsubsection{Cell Growth Inhibition Assay in Tumour Cell Lines and Primary Porcine Liver Cells}

The effects of the compounds on the in vitro growth of human tumor cell lines and non-tumor porcine liver primary cells were evaluated according to the procedure adopted by the NCI (USA) in their "In vitro Anticancer Drug Discovery Screen", using the SRB assay to assess cell growth [5-7].

For the cell lines, exponentially growing cells were obtained by plating $1.5 \times 10^{5}$ cells $/ \mathrm{mL}$ for MCF-7, $0.75 \times 10^{5}$ cells $/ \mathrm{mL}$ for A375-C5 and NCI-H460, and $5.0 \times 10^{5}$ cells $/ \mathrm{mL}$ for HepG2, followed 
by $24 \mathrm{~h}$ of incubation. For the primary porcine liver cells, cells were incubated in $96-$ well plates at a density of $5.0 \times 10^{5}$ cells $/ \mathrm{mL}$, and cultivated in DMEM medium with $10 \% \mathrm{FBS}, 100 \mathrm{U} / \mathrm{mL}$ penicillin and $100 \mathrm{mg} / \mathrm{mL}$ streptomycin.

Following a $24 \mathrm{~h}$ period to allow cells to adhere, cells were treated for $48 \mathrm{~h}$ with six serial dilutions of each test compound, starting from a maximum concentration of $125 \mu \mathrm{M}$. Following the $48 \mathrm{~h}$ treatment period, adherent cells were fixed in situ, washed and stained with SRB. The bound stain was solubilized and the absorbance was measured at $492 \mathrm{~nm}$ in the case of MCF-7, NCI-H460 and A375-C5 cells and at $515 \mathrm{~nm}$ in the case od HepG2 and PLP1 primary cells, in a plate reader (Biotek Instruments Inc., Powerwave XS, Bedfordshire, UK). Dose response curves were obtained and the concentration of the diarylamine that inhibited $50 \%$ of the net cell growth $\left(\mathrm{GI}_{50}\right)$ was calculated as described elsewhere [6-8]. Doxorubicin and ellipticine were used as positive controls of cell growth inhibition.

\subsubsection{Analysis of Cell Cycle Distribution Profile}

NCI-H460 cells were plated in 6-well plates at a final density of $1.5 \times 10^{5}$ cells/well and incubated at $37^{\circ} \mathrm{C}$ for $24 \mathrm{~h}$. Cells were then treated with compound $\mathbf{3 c}$ at its $\mathrm{GI}_{50}$ concentration $(1.4 \mu \mathrm{M})$. As controls, cells were also incubated with medium only (blank) and with the compound's vehicle (DMSO). Following $48 \mathrm{~h}$ of treatment, cells were fixed overnight in ice-cold $70 \%$ ethanol and re-suspended in PBS containing $0.1 \mathrm{mg} / \mathrm{mL}$ RNase A and $5 \mu \mathrm{g} / \mathrm{mL}$ propidium iodide. Cellular DNA content was analysed by flow cytometry using an Epics XL-MCL Coulter Flow cytometer (Brea, CA, USA) plotting at least 20,000 events per sample, as previously described [6,7]. The analysis of cell cycle distribution was subsequently performed using the FlowJo 7.2 software (Tree Star, Inc., Ashland, USA) after cell debris and aggregates exclusion.

\subsubsection{Analysis of Apoptosis}

Following $48 \mathrm{~h}$ treatment of NCI-H460 cells with compound 3c, as described above, the levels of apoptosis were analysed by flow cytometry using the Human Annexin V-FITC/PI apoptosis kit (Bender MedSystems, Vienna, Austria), according to the manufacturer's instructions. Flow cytometry was carried out using an Epics XL-MCL Coulter flow cytometer plotting at least 20,000 events per sample, as previously described [6,7]. The data was analysed using the FlowJo 7.2 software (Tree Star, Inc.).

\section{Conclusions}

From the three aminodi(hetero)arylamines synthesized, compound $\mathbf{3 c}$, with the $\mathrm{NH}_{2}$ group in ortho and an OMe group in para to the $\mathrm{NH}$ of the di(heteroarylamine, is the most promising antitumoral compound presenting the lowest $\mathrm{GI}_{50}$ values in all the human tumor cell lines studied. This compound did not show toxicity towards porcine liver non-tumor cells at those concentrations. In addition, all the aminodi(hetero)arylamines $\mathbf{3 a}-\mathbf{c}$ presented lower toxicity to non-tumor cells than the positive control, ellipticine $\left(\mathrm{GI}_{50}=4 \mu \mathrm{M}\right)$. Moreover, compound 3c caused a change in the cell cycle profile of the 
NCI-H460 cells, leading to a decrease in the percentage of cells in the G0/G1 phase of the cell cycle and caused an increase in the percentage of NCI-H460 apoptotic cells.

\section{Acknowledgements}

Foundation for the Science and Technology (FCT-Portugal) for financial support through the NMR Portuguese network (Bruker 400 Avance III-Univ Minho). FCT and FEDER (European Fund for Regional Development) for financial support through the research centers PEst-C/QUI/UI686/2011 and PEst-OE/AGR/UI0690/2011, the research project PTDC/QUI-QUI/111060/2009 and the post-Doctoral grants attributed to R.C.C. and R.T.L. (SFRH/BPD/68344/2010 and SFRH/BPD/68787/2010, respectively). IPATIMUP is an Associate Laboratory of the Portuguese Ministry of Science, Technology and Higher Education and is partially supported by FCT.

\section{Conflict of Interest}

The authors declare no conflict of interest.

\section{References and notes}

1. Bray, F.; Møller, B. Predicting the future burden of cancer. Nat. Ver. Cancer 2006, 6, 63-74.

2. Mimeault, M.; Batra S.K. New promising drug targets in cancer- and metastasis-initiating cells. Drug Discov. Today 2010, 15, 354-364.

3. Munchhof, M.J.; Beebe, J.S.; Casavant, J.M.; Cooper, B.A.; Doty, J.L.; Higdon, R.C.; Hillerman, S.M.; Soderstrom, C.I.; Knauth, E.A.; Marx, M.A.; et al. Design and SAR of thienopyrimidine and thienopyridine inhibitors of VEGFR-2 kinase activity. Bioorg. Med. Chem. Lett. 2004, 14, 21-24.

4. Zheng, R.-L.; Zhou, T.; He, H.-Y.; Liu, J.-Y.; Zheng, Y.; Tong, A.-P.; Xiang, M.-L.; Song, X.-R.; Yang, S.-Y.; Yu, L.-T.; et al. Novel thienopyridine derivatives as specific anti-hepatocellular carcinoma (HCC) agents: Synthesis, preliminary structure-activity relationships, and in vitro biological evaluation. Bioorg. Med. Chem. Lett. 2010, 20, 6282-6285.

5. Queiroz, M.J.R.P.; Calhelha, R.C.; Vale-Silva, L.A.; Pinto, E.; Nascimento, M.S.-J. Efficient synthesis of new 6-(hetero)arylthieno[3,2-b]pyridines by Suzuki-Miyaura Coupling. Evaluation of growth inhibition on human tumor cell lines. Eur. J. Med. Chem. 2010, 45, 5628-5634.

6. Queiroz, M.J.R.P.; Calhelha, R.C.; Vale-Silva, L.A.; Pinto, E.; Lima, R.T.; Vasconcelos, M.H. New 6-[(hetero)arylamino]thieno[3,2-b]pyridines: Synthesis and antitumoral activities. Eur. J. Med. Chem. 2010, 45, 5732-5738.

7. Queiroz, M.J.R.P.; Calhelha, R.C.; Vale-Silva, L.A.; Pinto, E.; Almeida, G.M.; Vasconcelos, M.H. Synthesis and evaluation of tumor cell growth inhibition of novel methyl 3-Amino-6[(hetero)arylethynyl]thieno[3,2-b]pyridine-2-carboxylates. Structure-activity relationships and effects on the cell cycle and apoptosis. Eur. J. Med. Chem. 2011, 46, 236-240.

8. Dunn, A.D.; Norrie, R.J.J. Nucleophilic displacement in pyridine ring. J. Heterocycl. Chem. 1987, 24, 85-89. 
9. Yin, J.; Zhao, M.M.; Hulfman, M.A.; McWamara, J.M. Pd-catalyzed N-arylation of heteroarylamines. Org. Lett. 2002, 4, 3481-3484.

10. Queiroz, M.-J.R.P.; Calhelha, R.C.; Kirsch, G. Reactivity of several deactivated 3-aminobenzo $[b]$ thiophenes in the Buchwald-Hartwig C-N coupling. Scope and limitations. Tetrahedron 2007, 63, 13000-13005.

11. Dai, Y.; Guo, Y.; Frey, R.R.; Ji, Z.; Curtin, M.L.; Ahmed, A.A.; Albert, D.H.; Arnold, L.; Arries, S.S.; Barlozzari, T.; et al. Thienopyrimidine ureas as novel and potent multitargeted receptor tyrosine kinase inhibitors. J. Med. Chem. 2005, 48, 6066-6083.

12. Queiroz, M.J.R.P.; Calhelha, R.C. Synthesis of new thieno[3,2-b]pyridine derivatives by palladium-catalyzed couplings and intramolecular cyclizations. Tetrahedron Lett. 2010, 51, 281-283.

13. Abreu, R.M.V.; Ferreira, I.C.F.R; Calhelha, R.C.; Lima, R.T.; Vasconcelos, M.H.; Adega, F.; Chaves, R.; Queiroz, M.J.R.P. Anti-hepatocellular carcinoma activity using HepG2 cells and hepatotoxicity of 6-substituted methyl 3-aminothieno[3,2-b]pyridine-2-carboxylate derivatives: In vitro evaluation, cell cycle analysis and QSAR studies. Eur. J. Med. Chem. 2011, 46, 5800-5806.

Sample Availability: Contact the authors.

(C) 2012 by the authors; licensee MDPI, Basel, Switzerland. This article is an open access article distributed under the terms and conditions of the Creative Commons Attribution license (http://creativecommons.org/licenses/by/3.0/). 